\title{
Further Investigation of the Repetitive Failure in an Aircraft Engine Cylinder Head - Mechanical properties of Aluminum alloy 242.0
}

\author{
Nikola VUČETIĆ *, Gordana JOVIČIĆ **, Branimir KRSTIĆ****, Miroslav ŽIVKOVIĆ**, \\ Vladimir MILOVANOVIĆ**, Josip KAČMARČIK****, Ranko ANTUNOVIĆ* \\ *University of East Sarajevo, Faculty of Mechanical Engineering, Vuka Karadžića 30, 71123 East Sarajevo, Bosnia and \\ Herzegovina,E-mail:nikola.vucetic@ues.rs.ba; ranko.antunovic@ues.rs.ba \\ **University of Kragujevac, Faculty of Engineering, Sestre Janjić 6, 34000 Kragujevac, Serbia, \\ E-mail: gordana.jovicic@kg.ac.rs; zile@kg.ac.rs; vladicka@kg.ac.rs \\ ***University of Defence in Belgrade, Military Academy, Pavla Jurišića Śturma 33, 11000 Belgrade, Serbia, \\ E-mail: branimir.krstic@va.mod.gov.rs \\ ****University of Zenica, Faculty of Mechanical Engineering, Fakultetska 1, 72000 Zenica, Bosnia and Herzegovina, \\ E-mail: kjosip@mf.unze.ba
}

cross $^{\text {ref }}$ http://dx.doi.org/10.5755/j01.mech.26.4.24556

\section{Introduction}

Mechanical failures of different aircraft structural components are common case in practice [1-12]. There are numerous causes of failure such as corrosion, porosity, high cycle fatigue and the like. In modern aviation industry these elements have to satisfy an increased level of reliability during operation. In order to prevent the failure of individual components, it is important to know mechanical properties of the materials from which they are made. Fatigue failure may occur in any engineering components that are subjected to cyclic loading below the material ultimate strength. Findlay et al. assessed the failure mechanisms frequency in aircraft components [13], Table 1.

Table 1

Fracture mechanism frequency

\begin{tabular}{|c|c|}
\hline Failure mechanism & $\begin{array}{c}\text { Failure mechanism frequency } \\
\text { in aircraft components, } \%\end{array}$ \\
\hline Fatigue & 55 \\
\hline Corrosion & 16 \\
\hline Overload & 14 \\
\hline $\begin{array}{c}\text { Stress corrosion, fatigue } \\
\text { corrosion }\end{array}$ & 7 \\
\hline Wear, abrasion, erosion & 6 \\
\hline High temperature corrosion & 2 \\
\hline
\end{tabular}

The results from Table 1 show that the the fatigue of the constituent components is dominant cause of the aircraft components failure [14-17].

One of the more frequent mechanical failures on air-cooled piston engines is cylinder head cracking. Based on reports from the competent aviation authorities of countries around the world [18-21] there have been even 47 such failures on conventional air-cooled engines. Each cylinder assembly (cylinder), constituting the body of the cylinder and cylinder head, is a special unit with distinctive and clearly expressed deep cooling ribs on the outside. This paper presents a continuation of the study of the training aircraft Utva-75 cylinder head fracture cause [22]. B. Krstić et. al [22] performed visual inspection of the fractured aircraft cylinder head. The crack between cylinder head fifth and sixth cooling rib has been noticed. The research included microfractographic, macrofractographic and metallographic examinations of the cylinder head fractured surface. Also, within the research, finite element analysis of the cylinder assembly at room temperature was done.

The research of this paper is based on the experimental analysis and numerical simulations of mechanical properties of Aluminum alloy 242.0 which is the constituent material of the Lycoming IO-360-B1F aircraft engine cylinder head. The basic application of this alloy is production of air-cooled cylinder heads [23]. The special significance, contribution and complexity of the research is reflected in the fact that there are no papers in literature related to the experimental determination of the Aluminum alloy 242.0 mechanical properties and S-N curve forming in contrast to the numerous Aluminum alloys that were frequently subject of research by numerous authors [24-29]. Based on chemical, metallographic, static and dynamic experimental tests of the material properties, Aluminum alloy 242.0 static and fatigue properties were obtained, S-N curve was formed and endurance limit was determined. The stress-life (S-N) curve provides useful fatigue data for estimating the number of cycles to failure of material at a certain level of applied stress [30]. Numerical simulations of experiments were made to confirm numerical procedures due to further research. The simulations results were confirmed by experimental results. The results of the research are planned to be implemented in further numerical research of Lycoming IO-360-B1F cylinder assembly integrity assessment, above all for the static (stress-strain) analysis and dynamic (fatigue) analysis of the cylinder head at room and at elevated temperature.

\section{Experimental procedure}

\subsection{Chemical composition and metallography}

Chemical composition analysis of Aluminum alloy 242.0 was carried out using X-ray fluorescence spectroscopy at the Laboratory for Material/Products Testing within the company J.S.C. Orao from Bijeljina. Results are shown in Table 2.

Chemical composition analysis results completely match the standard specification for Aluminum alloy 242.0. 
Aluminum alloy 242.0 chemical composition analysis results

\begin{tabular}{|c|c|c|c|c|c|c|c|c|c|}
\hline Element & $\mathrm{Cu}$ & $\mathrm{Cr}$ & $\mathrm{Fe}$ & $\mathrm{Mg}$ & $\mathrm{Mn}$ & $\mathrm{Ni}$ & $\mathrm{Si}$ & $\mathrm{Ti}$ & $\mathrm{Zn}$ \\
\hline $\begin{array}{c}\text { Standard } \\
\text { specification, \% }\end{array}$ & 4.02 & 0.20 & 0.45 & 1.52 & 0.06 & 2.29 & 0.46 & 0.15 & 0.03 \\
\hline Analysis results, \% & $(3.5-4.5)$ & $(0-0.25)$ & $(0-1.0)$ & $(1.2-1.8)$ & $(0-0.35)$ & $(1.7-2.3)$ & $(0-0.7)$ & $(0-0.25)$ & $(0-0.35)$ \\
\hline
\end{tabular}

In order to better interpret and understand experimental and numerical results obtained in next chapters, the structure of tested specimen was examined using a digital microscope VHX 6000 at Faculty of Mechanical Engineering in Ljubljana, Fig. 1.

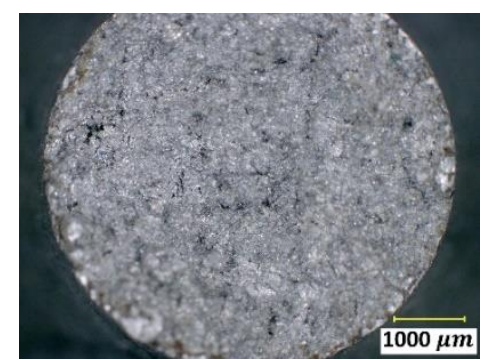

Fig. 1 Aluminum alloy 242.0 specimen for metallographic examination

The sample was sanded with a sandpaper fineness up to 2500 and then it was polished with a diamond paste, Fig. 2.

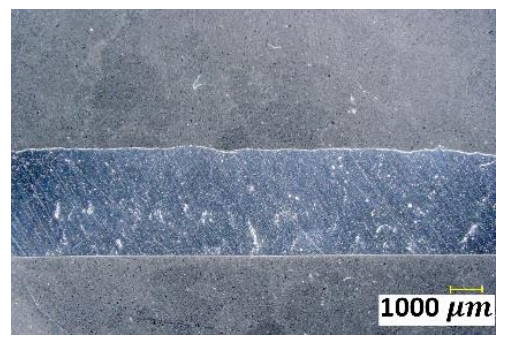

Fig. 2 Preparation of sample for metallographic examination

Material metallography was carried out using 150x-1000x microscope magnification.

The microstructure examination revealed the typical structure of an Aluminum - Copper casting alloy with intermetallic phases precipitates located at the grain boundaries, Fig. 3.

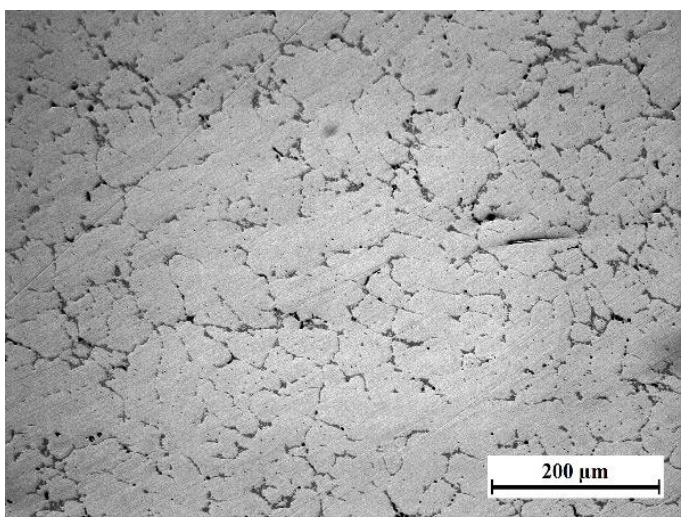

Fig. 3 Aluminum alloy 242.0 microstructure

On the basis of the observed specimens surface, it is possible to determine the existence of a large number of defects in materials characteristic for the casting process.
The microporosity of the material in the form of clustered cavities surrounded by primary dendrites and eutectic phase is particularly dominant, Fig. 4.

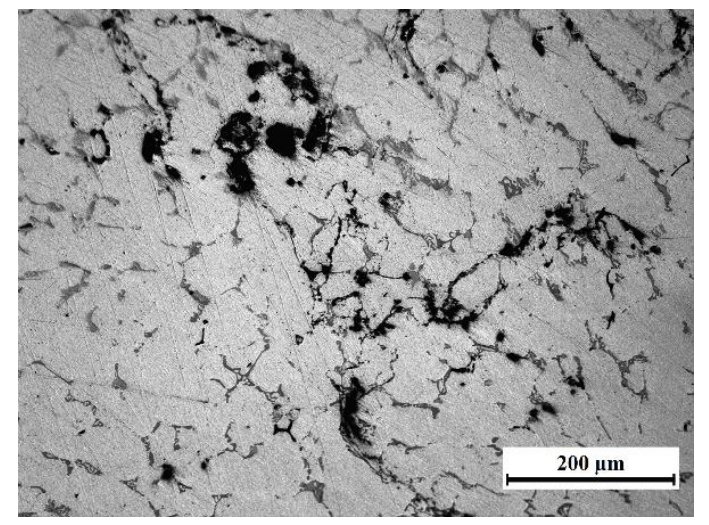

Fig. 4 Microporosity of material in a form of grouped shrinkage pores

The dimensions of microporous cavities are in range from 50 to $200 \mu \mathrm{m}$, Fig. 5 .

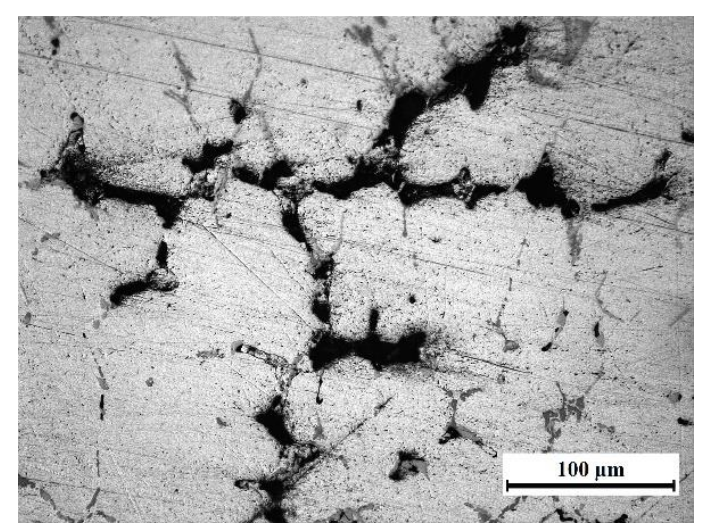

Fig. 5 Typical shrinkage pore (black) surrounded by primary dendrites (white) and eutectic phase (gray needles in a white matrix)

Intergranular cracks, formed by linking up of other shrinkage pores in material were, also, observed, Fig. 6.

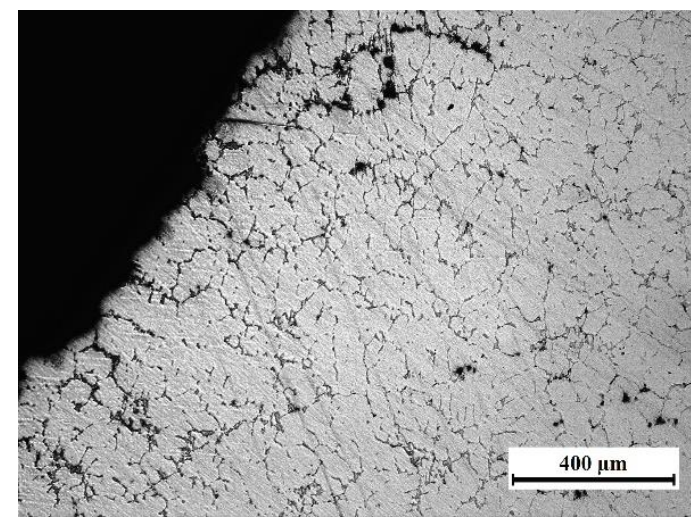

Fig. 6 Metallographic section showing the intergranular crack due to the linking of the shrinkage pores 


\subsection{Static properties examination}

Aluminum alloy 242.0 static properties examination was performed on six specimens at room temperature $\left(23 \pm 5^{\circ} \mathrm{C}\right)$. Dimensions and shape of specimens were machined in accordance with B 557M standard [31], Figs. $7 \mathrm{a}-\mathrm{b}$.

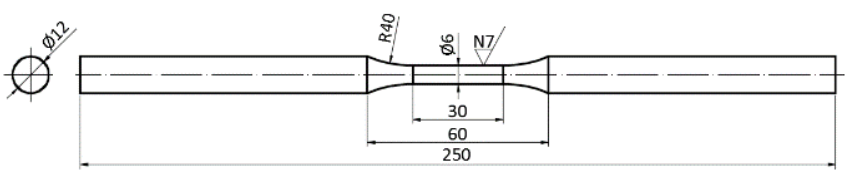

a

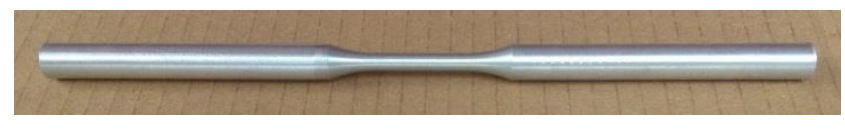

b

Fig. 7 Specimen for static properties examination at room temperature: a) dimensions; b) shape

In order to ensure the quality of results obtained, all specimens were polished before examination. The tested specimens were manufactured in CNC Machine Tools and CIM Systems Laboratory at the Faculty of Mechanical Engineering in East Sarajevo.

Mechanical properties testing of Aluminum alloy 242.0 specimens was performed using servo-hydraulic SHIMADZU testing machine type EHF EV101K3-070-0 in accordance with standard B 557M [31]. Tests were carried out at the Center for Engineering Software and Dynamic Testing at the Faculty of Engineering in Kragujevac.

Table 3 shows experimental determined static properties of Aluminum alloy 242.0.

Table 3

Static properties of Aluminum alloy 242.0

\begin{tabular}{|c|c|c|}
\hline $\begin{array}{c}\text { Specimen } \\
\text { designation }\end{array}$ & $\begin{array}{c}\text { Yield stress } \sigma_{y}, \\
\mathrm{MPa}\end{array}$ & $\begin{array}{c}\text { Tensile strength } R_{m}, \\
\mathrm{MPa}\end{array}$ \\
\hline $1-\mathrm{S}$ & 199.7 & 205.7 \\
\hline $2-\mathrm{S}$ & 166.92 & 198.4 \\
\hline $3-\mathrm{S}$ & 156.2 & 192.5 \\
\hline $4-\mathrm{S}$ & 148.5 & 186.7 \\
\hline $5-\mathrm{S}$ & 178.6 & 201.3 \\
\hline $6-\mathrm{S}$ & 152.2 & 190.8 \\
\hline
\end{tabular}

The designation system for tested specimens is such that the number presents specimen serial number, while the letter $S$ in the designation indicates that the test was performed at room temperature.

\subsection{Fatigue properties examination}

The essence of testing the material fatigue properties is to determine the dynamic strength, the stress that the material can withstand at unlimited number of load cycle changes without fracture.

Fatigue properties examination of Aluminum 242.0 was performed on fifteen specimens at room $\left(23 \pm 5^{\circ} \mathrm{C}\right)$ temperature. Material fatigue properties, due high cycle load, were obtained on the basis of results for uniaxial, cyclically loaded specimens (fully reversed load) with $R=-1$ stress ratio examination. Specimens were exposed to high cycle fatigue under controlled stress conditions in accordance with ASTM E468-90 [32] and ASTM E606-92
[33] standards. Dimensions and shape of specimen for fatigue properties examination at room temperature are shown in Figs. $8 \mathrm{a}-\mathrm{b}$.

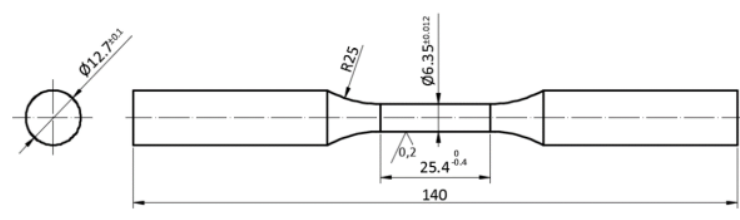

a

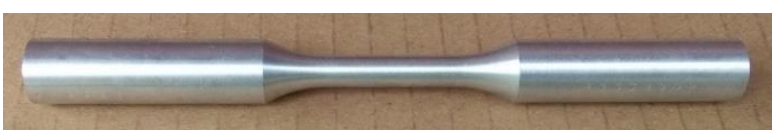

b

Fig. 8 Specimen for fatigue properties examination at room temperature: a) dimensions; b) shape

All specimens for fatigue testing were machined in CNC Machine Tools and CIM Systems Laboratory at the Faculty of Mechanical Engineering in East Sarajevo.

Fatigue properties testing of Aluminum alloy 242.0 specimens was performed at the Center for Engineering Software and Dynamic Testing at the Faculty of Engineering in Kragujevac using servo-hydraulic SHIMADZU testing machine. Specimens were tested under uniaxial, fully reversed (tensile - compression) testing with $R=-1$ stress ratio. During the fatigue properties testing frequency was $10 \mathrm{~Hz}-20 \mathrm{~Hz}$, stress amplitude 30-100 MPa, whereby, as a failure criterion or crack initialization a rapid loss of stiffness, or stress amplitude decreasing by $10 \%$ was taken. Table 4 shows the experimentally obtained results under stress controlled conditions.

Table 4

Specimens uniaxial, fully reversed testing with stress ratio $R=-1$ results

\begin{tabular}{|c|c|c|c|}
\hline $\begin{array}{c}\text { Specimen } \\
\text { designation }\end{array}$ & $\begin{array}{c}\text { Stress amplitude } \\
\sigma_{a}, \mathrm{MPa}\end{array}$ & $\begin{array}{c}\text { Frequency, } \\
\mathrm{Hz}\end{array}$ & $\begin{array}{c}\text { Number of } \\
\text { cycles } N_{f}\end{array}$ \\
\hline $1-\mathrm{S}$ & 100 & 10 & 1764 \\
\hline $2-\mathrm{S}$ & 95 & 10 & 2683 \\
\hline $3-\mathrm{S}$ & 90 & 10 & 4237 \\
\hline $4-\mathrm{S}$ & 85 & 10 & 8090 \\
\hline $5-\mathrm{S}$ & 80 & 10 & 16878 \\
\hline $6-\mathrm{S}$ & 75 & 10 & 32606 \\
\hline $7-\mathrm{S}$ & 70 & 10 & 64844 \\
\hline $8-\mathrm{S}$ & 65 & 10 & 98110 \\
\hline $9-\mathrm{S}$ & 60 & 20 & 201590 \\
\hline $10-\mathrm{S}$ & 55 & 20 & 392380 \\
\hline $11-\mathrm{S}$ & 50 & 20 & 797690 \\
\hline $12-\mathrm{S}$ & 45 & 20 & 1430640 \\
\hline $13-\mathrm{S}$ & 40 & 20 & 26843700 \\
\hline $14-\mathrm{S}$ & 35 & 20 & 67342900 \\
\hline $15-\mathrm{S}$ & 30 & & \\
\hline & & 20 & \\
\hline
\end{tabular}

Specimens designation was done in the same way as specimens designation during static properties test examination.

Fig. 9 shows Aluminum alloy 242.0 semi-log plot of the stress amplitude versus the number of cycles to failure at room temperature.

The S-N curve shows that fatigue life generally increases with decreasing cyclic stress. The S-N curve was developed using curve fitting of tabular data according to the Basquin's equation which can be written as [29]: 


$$
\sigma_{a}=\sigma_{f}^{\prime}\left(N_{f}\right)^{b}
$$

where: $\sigma_{a}$ is the stress amplitude; $\sigma_{f}^{\prime}$ and $b$ are the material constants and $N_{f}$ is the number of cycles to failure.

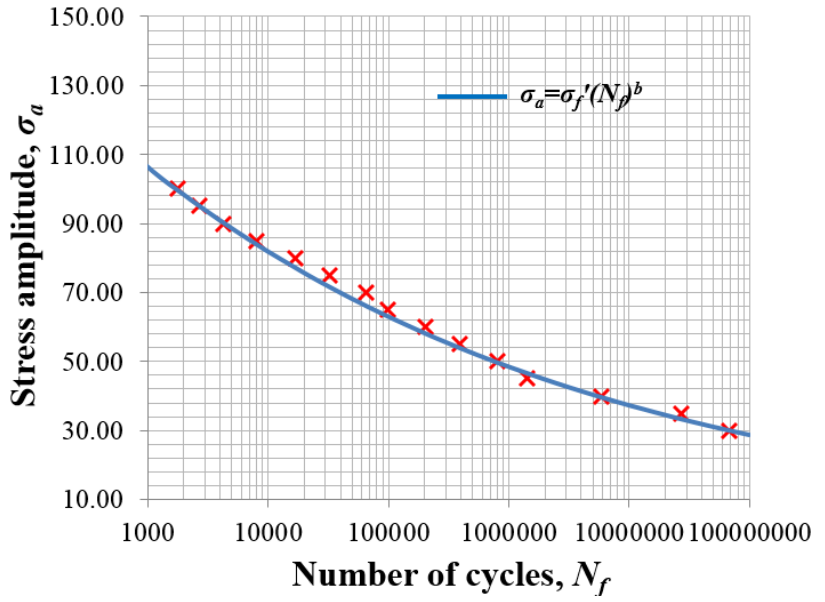

Fig. 9 Semi-log S-N curve for uniaxial, fully reversed Aluminum alloy 242.0 specimens testing

From the curve fitting, the values of the material constants $\sigma_{f}^{\prime}$ and $b$ were determined, Table 5 .

Table 5

Aluminum alloy 242.0 specimens fatigue properties under uniaxial, fully reversed load

\begin{tabular}{|c|c|}
\hline Properties & Value \\
\hline Fatigue strength coefficient $\sigma_{f}^{\prime}$ & $252.9 \mathrm{MPa}$ \\
\hline Fatigue strength exponent $b$ & -0.114 \\
\hline
\end{tabular}

\section{Numerical simulations}

3.1. Tensile test simulation

Numerical simulation of Aluminum alloy 242.0

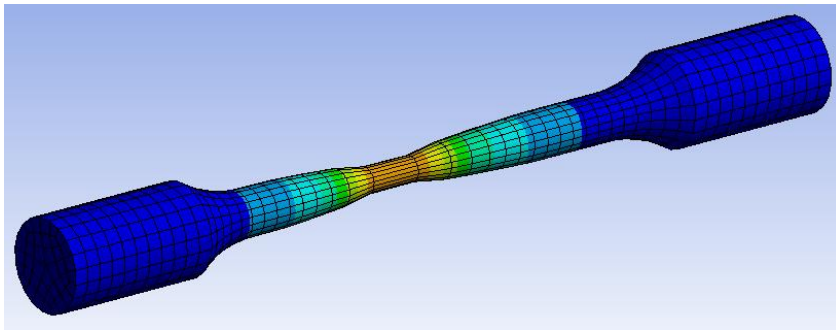

a

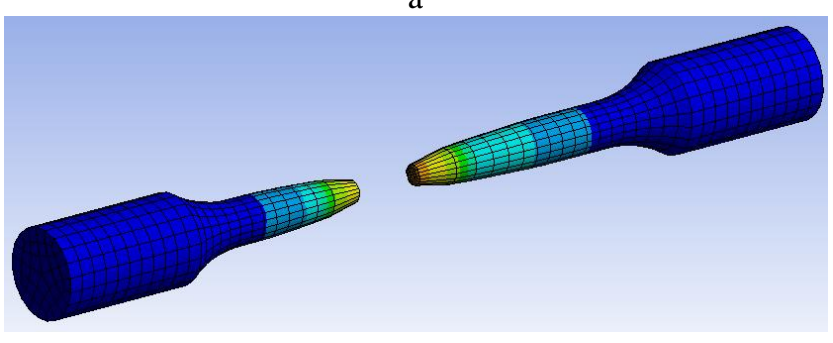

b

Fig. 10 Ansys Workbench specimen Tensile test: a) specimen neck forming; b) specimen break tensile test was performed using Ansys Workbench Explicit Dynamics. Aluminum alloy 242.0 material properties, obtained by experimental test, were defined and specimen model was created. After that finite element mesh was generated and it consisted of 2160 elements with default size and 2805 nodes.

Testing conditions were simulated on the basis of experimental test set up. Specimen was fixed on one side. Figs. $10 \mathrm{a}$ and $\mathrm{b}$ shows specimen neck forming and specimen break during testing process at room temperature.

By simulating tensile test numerically, Aluminum 242.0 tensile ttrength at room temperature of $202 \mathrm{MPa}$ was determined. By Ansys Workbench numerical simulation test equivalent plastic strain for Aluminum 242.0 specimen of $1.24 \%$ was obtained.

\subsection{Fatigue test simulation}

Numerical fatigue simulation was performed using Ansys Workbench Static Structural analysis, Fig. 11. After defining material properties on the basis of experimental test, mesh and boundary conditions (one side fixed), applied fully reversed stress $(R=-1) 30-100 \mathrm{MPa}$ was varied.

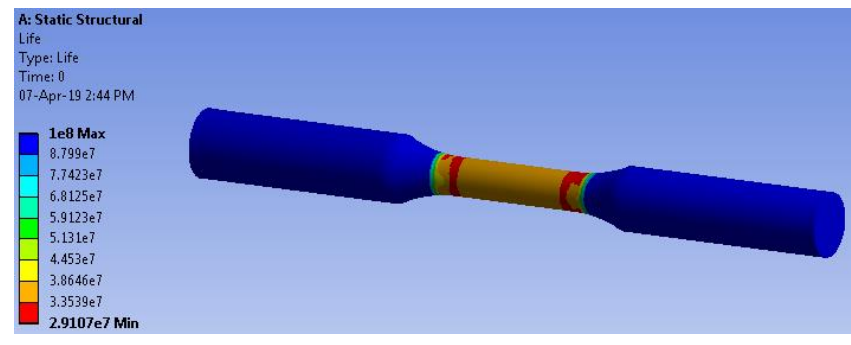

Fig. 11 Fatigue life numerical result for applied stress of $35 \mathrm{MPa}$

Finite element mesh with medium smoothing consisted of 1188 elements with default size and 5860 nodes.

Results were shown in Table 6 and in Fig. 12.

Table 6

Aluminum alloy 242.0 numerical simulation results for specimens uniaxial, fully reversed testing with stress ratio $R=-1$

\begin{tabular}{|c|c|}
\hline Stress amplitude $\sigma_{a}, \mathrm{MPa}$ & Number of cycles $N_{f}$ \\
\hline 100 & 1909 \\
\hline 95 & 2921 \\
\hline 90 & 4470 \\
\hline 85 & 8726 \\
\hline 80 & 18583 \\
\hline 75 & 38044 \\
\hline 70 & 66584 \\
\hline 65 & 116530 \\
\hline 60 & 222220 \\
\hline 55 & 441860 \\
\hline 50 & 882740 \\
\hline 45 & 1817200 \\
\hline 40 & 6206100 \\
\hline 35 & 29107400 \\
\hline 30 & 100000000 \\
\hline
\end{tabular}




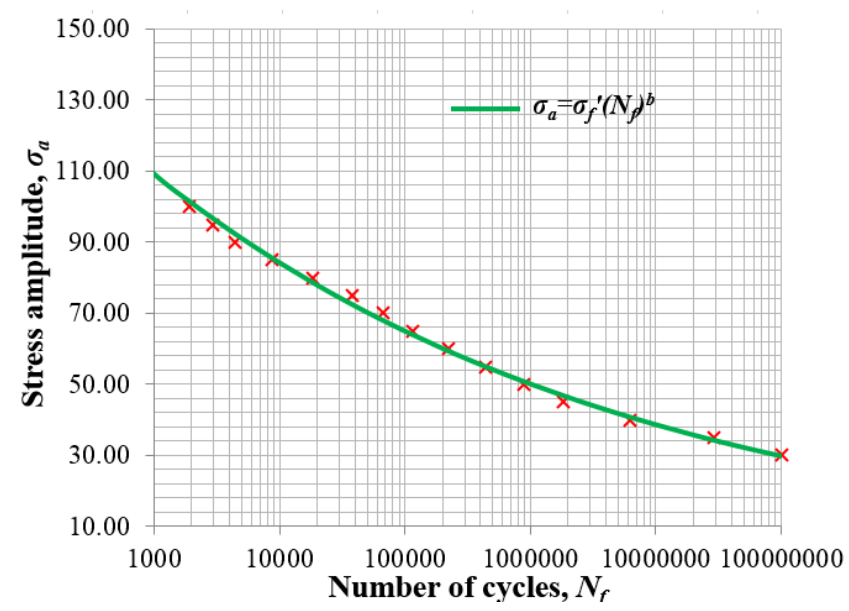

Fig. 12 Aluminum alloy $242.0 \mathrm{~S}-\mathrm{N}$ curve obtained by numerical simulations

Table 7 shows Aluminum alloy 242.0 fatigue properties obtained by numerical simulations.

Table 7

Aluminum 242.0 fatigue properties obtained by numerical simulations

\begin{tabular}{|c|c|}
\hline Properties & Value \\
\hline Fatigue strength coefficient $\sigma_{f}{ }^{\prime}$ & $257.9 \mathrm{MPa}$ \\
\hline Fatigue strength exponent $b$ & -0.113 \\
\hline
\end{tabular}

\section{Results and discussion}

Table 8 shows comparative results of Aluminum alloy 242.0 tensile strength obtained based on experimental tests and numerical simulations.

Table 8

Aluminum 242.0 Tensile Strength comparative results

\begin{tabular}{|c|c|}
\hline Test type & Tensile strength $R_{m}, \mathrm{MPa}$ \\
\hline Experimental test (mean value) & 195.9 \\
\hline Numerical simulations & 202 \\
\hline
\end{tabular}

On the basis of results it can be concluded that maximum deviation numerical to experimental results of tensile strength is $7.6 \%$ and, looking into mean value of tensile strength obtained by the experiment, numerical to experimental results deviation amounts to $3 \%$. Deviation of results and somewhat more value of numerical results are primarily due to material homogeneity during numerical simulations. It can be concluded that the numerical simulations were confirmed by experiment. Since numerical simulations give approximate results in comparison with experiment, it will make them reliable to apply in the numerical assessment of the cylinder assembly integrity that will be the subject of further research.

Table 9 shows numerical to experimental fatigue test results deviation.

Number of cycles to failure of 67342900 is obtained experimentally for stress amplitude of $30 \mathrm{MPa}$ and this stress presents the material endurance limit. Number of cycles to failure for Aluminum alloys are within limits $10^{7}$ $10^{8}$. Numerical simulations gave result of $10^{8}$ cycles to failure. A larger number of cycles to failure is, probably, due to material homogeneity during numerical analysis.
Fig. 13 shows comparative Aluminum alloy 242.0 S-N curves obtained by both experimental tests and numerical simulations.

Table 9

Numerical to experimental fatigue test results deviation

\begin{tabular}{|c|c|c|c|}
\hline \multirow{3}{*}{$\begin{array}{c}\text { Stress } \\
\text { amplitude } \\
\sigma_{a}, \mathrm{MPa}\end{array}$} & \multicolumn{2}{|c|}{ Results } & \multirow{3}{*}{$\begin{array}{c}\text { Numerical to } \\
\text { experimental } \\
\text { results deviation, } \\
\%\end{array}$} \\
\hline & Experimental & Numerical & \\
\hline & $\begin{array}{c}\text { Number of } \\
\text { cycles } N_{f}\end{array}$ & $\begin{array}{c}\text { Number of } \\
\text { cycles } N_{f}\end{array}$ & \\
\hline 100 & 1764 & 1909 & 7.6 \\
\hline 95 & 2683 & 2921 & 8.1 \\
\hline 90 & 4237 & 4470 & 5.2 \\
\hline 85 & 8090 & 8726 & 7.3 \\
\hline 80 & 16878 & 18583 & 9.2 \\
\hline 75 & 32606 & 38044 & 14.3 \\
\hline 70 & 64844 & 66584 & 2.6 \\
\hline 65 & 98110 & 116530 & 15.8 \\
\hline 60 & 201590 & 222220 & 9.3 \\
\hline 55 & 392380 & 441860 & 11.2 \\
\hline 50 & 797690 & 882740 & 9.6 \\
\hline 45 & 1430640 & 1817200 & 21.3 \\
\hline 40 & 5930700 & 6206100 & 4.4 \\
\hline 35 & 26843700 & 29107400 & 7.8 \\
\hline 30 & 67342900 & 100000000 & 32.7 \\
\hline
\end{tabular}



Fig. 13 Aluminum alloy 242.0 comparative S-N curves obtained by both experimental tests and numerical simulations

The S-N curve obtained on the basis of the experiment is shown in blue and the $\mathrm{S}-\mathrm{N}$ curve obtained on the basis of the numerical simulations is shown in orange on the diagram in Fig. 13. It can be noticed that minimal number of cycles results deviation is $2,6 \%$ and maximum is $32,7 \%$ and it corresponds to the lowest applied stress of 30 $\mathrm{MPa}$. A greater deviation in the results, expressed in a higher number of cycles, may be conditioned by the microstructure of the tested material discussed in the first chapter.

Defects in the material both represent the potential places of the cracks formation and decrease mechanical properties, as well as the lifetime of the material due to fatigue, both by reducing the crack propagation time and by shortening the crack initiation time [3, 4]. It has been found that the materials fatigue life, obtained by casting Aluminum alloys containing casting defects in the form of pores or cavities, can be shorter two or more times compared to materials without these defects $[34,35]$. The decrease in the material fatigue is in reverse proportion to the size of the porous forms [36-40]. 
Impact fracture toughness results, which are not shown in this paper, were obtained within material properties experimental research. With the appearance of the specimen cross section fracture, it was concluded that the fracture mechanism indicates the brittle fracture character. Those results and material fracture mechanism are going to be used to make it easier to clarify the analysis of the crack appearance on cylinder head and it's failure in further Lycoming IO-360-B1F cylinder assembly research.

\section{Conclusions}

The frequent use of Aluminum alloy 242.0 for military and aviation purposes, on the one hand, and the lack of experimental research data of mentioned alloy, on the other hand, have led to the subject of this paper research. The set up of experimental tests carried out in this paper were defined by studyng the standards for mechanical testing of materials and by their systematization. The tests included the confirmation of chemical composition of the tested material, metallographic examination and experimental tests and numerical simulations of the material static and fatigue properties at room temperature. Based on the previous tests, high cycle fatigue $\mathrm{S}-\mathrm{N}$ curve was formed and endurance limit of tested material was determined. The microporosity of the material in the form of clustered cavities surrounded by primary dendrites and eutectic phase is particularly dominant. It can leads to the interconnection of adjacent cavities in the material and formation of initial cracks in the case of very complex and variable loads to whom material, such as examined, during exploitation can be exposed. The porosity of the material is, most often, the consequence of a poorly designed casting process. The obtained numerical simulations results, confirmed by experimental results, are going to serve as a starting point in further analyses of the failure of Lycoming IO-360-B1F cylinder assembly made from the tested alloy, primarily in numerical analysis. The research results are going to be implemented in numerical modeling of the cylinder assembly stress-strain state with induction of thermal loads. Agreeing the results of numerical simulations with experimental results indicates the applicability of FEM analysis to further research that would include development of a methodology for the numerical integrity assessment of the aircraft air cooled piston cylinder assembly exposed to high cycle variable thermodynamic loads and could be applicable to other structural elements and to other internal combustion engines. The aforementioned methodology would provide an effective and efficient numerical tool that would be used in a simple and quick way to assess the integrity estimation of the piston engine cylinder assembly which would result in significant improvements in the design, production and testing costs of the vital elements of the internal combustion engines.

\section{References}

1. Bagnoli, F.; Dolce, F.; Colavita, M.; Bernabei, M. 2008. Fatigue fracture of a main landing gear swinging lever in a civil aircraft, Engineering Failure Analysis 15(6): 755-765.

https://doi.org/10.1016/j.engfailanal.2007.06.012.
2. Bagnoli, F.; Bernabei, M.; Ciliberto, A. 2011. Failure analysis of an aircraft auxiliary power unit air intake door, Engineering Failure Analysis 18(1): 284-294, https://doi.org/10.1016/j.engfailanal.2010.09.007.

3. Esaklul, K. 1992. Handbook of Case Histories in Failure Analysis, ASM International, Vol. 1, Ohio.

4. Esaklul, K. 1994. Handbook of Case Histories in Failure Analysis, ASM International, Vol. 2, Ohio.

5. Aviation Safety Experts. Aircraft Engine Failures, from http://www.dviaviation.com/engine-failures.html, 14.03.2017.

6. Flying. Aftermath: A Pattern of Failure, from http://www.flyingmag.com/technique/accidents/afterma th-pattern-failure, 14.03.2017.

7. Kolkman, H. J.; Kool, G.; Wanhill, R. J. H. 1996. Aircraft crash caused by stress corrosion cracking, Journal of Engineering for Gas Turbines and Power 118(1): 146-149, https://doi.org/10.1115/1.2816530.

8. Ortiz, A. F.; Rodriguez, S. A.; Coronado, J. J. 2013. Failure analysis of the engine cylinder of a training aircraft, Engineering Failure Analysis 35: 686-691, https://doi.org/10.1016/j.engfailanal.2013.06.010.

9. Allegrucci, L.; Amura, M.; Bagnoli, F.; Bernabei, M. 2009. Fatigue fracture of a aircraft canopy lever reverse, Engineering Failure Analysis 16(1): 391-401. https://doi.org/10.1016/j.engfailanal.2008.05.010.

10. Diltemiz, S. F.; Uzunonat, Y.; Kushan, M. C.; Celik, O. N. 2009. Effect of dent geometry on fatigue life of aircraft structural cylinder part, Engineering Failure Analysis 16(4): 1203-1207.

https://doi.org/10.1016/j.engfailanal.2008.07.017.

11. Zhongjian, P.; Qinghua, H. 2015. High cycle fatigue analysis for oil pan of piston aviation kerosene engine, Engineering Failure Analysis 49: 104-112, https://doi.org/10.1016/j.engfailanal.2014.12.009.

12. Kushan, M. C.; Diltemiz, S. F.; Sackesen, I. 2007. Failure analysis of an aircraft propeller, Engineering Failure Analysis 14(8): 1693-1700,

https://doi.org/10.1016/j.engfailanal.2006.11.069.

13. Findlay, S. J.; Harrison, N. D. 2002. Why aircraft fail, MaterialsToday 5(11): 18-25. https://doi.org/10.1016/S1369-7021(02)01138-0.

14.Silva, F. S. 2006. Fatigue on engine pistons-a compendium of case studies, Engineering Failure Analysis 13(3): 480-492, https://doi.org/10.1016/j.engfailanal.2004.12.023.

15. Yu, Z. W.; Xu, X. L. 2006. Failure analysis and metallurgical investigation of diesel engine exhaust valves, Engineering Failure Analysis 13(4): 673-682. https://doi.org/10.1016/j.engfailanal.2004.10.018.

16. Martin, G. G . 2004. Failure of stationary pump engine piston, Journal of Failure Analysis and Prevention 4(1): 37-39. https://doi.org/10.1361/15298150417881.

17. Yu, Z. W.; Xu, X. L. 2005. Failure analysis of a diesel engine crankshaft, Engineering Failure Analysis 12(3): 487-495. https://doi.org/10.1016/j.engfailanal.2004.10.001.

18. Federal Aviation Administration of the USA. Airworthiness Directive (AD), from 
https://www.faa.gov/regulations_policies/airworthiness_directives/search/?q=2008\&make-

Model $=\&$ type $=$ Current $\&$ filter $=\&$ sort $=$ effective -

Date\&direction=asc, 15.03.2019.

19. National Transportation Safety Board of the USA. Safety recommendation A-12-7, from

https://www.ntsb.gov/_layouts/ntsb.recsearch/Recomm endation.aspx?Rec=A-12-007, 12.03.2019.

20. Guertsman, V.; Dionne, S.; Crosby, T. 2009. Engineering report number LP085/2009, Transportation Safety Board of Canada.

21. Guertsman, V.; Dionne, S.; Crosby, T. 2010. Engineering report number LP077/2010, Transportation Safety Board of Canada.

22. Krstić, B.; Rašuo, B.; Trifković, D.; Radisavljević, I.; Rajić, Z.; Dinulović, M. 2013. Failure analysis of an aircraft engine cylinder head, Engineering failure analysis 32: 1-15.

https://doi.org/10.1016/j.engfailanal.2013.03.004.

23. Rašuo, B. 1995. Tehnologija proizvodnje letjelica. Mašinski fakultet, Beograd.

24. Liang, X.; Xiang, Y.; Li, H.; Song, Z. 2016. Fatigue life prediction of aviation aluminium alloy based on quantitative pre-corrosion damage analysis, Transactions of Nonferrous Metals Society of China 27(6): 1353-1362 https://doi.org/10.1016/S1003-6326(17)60156-0.

25. Borrego, L. P.; Abreu, L. M.; Costa, J. M.; Ferreira, J. M. 2004. Analysis of low cycle fatigue in AlMgSi aluminium alloys, Engineering Failure Analysis 11(5): 715-725.

https://doi.org/10.1016/j.engfailanal.2003.09.003.

26. Couper, M. J.; Nesson, A. E.; Griffiths, J. R. 1990. Casting defects and the fatigue behavior of an aluminium casting alloy, Fatigue and Fracture of Engineering Materials and Structures 13: 213-227. https://doi.org/10.1111/j.1460-2695.1990.tb00594.x.

27. Casari, D.; Fortini, A.; Merlin, M. 2013. Fracture behaviour of grain refined A356 cast aluminium alloy: tensile and Charpy impact specimens, XXII Convegno Nazionale IGF, Roma, Italia, 1st-3rd Luglio, pp. 314321.

28. Tocci, M.; Pola, A.; Montesano, L.; Merlin, M.; Garagnani, G. L.; La Vechia, G. M. 2017. Tensile behaviour and impact toughness of an AlSi3MgCr alloy, Procedia Structural Integrity 3: 517-525. https://doi.org/10.1016/j.prostr.2017.04.053.

29. Jurczak, W.; Kyziol, L. 2012. Dynamic properties of 7000 - series aluminum alloys at large strain rates, Polish Maritime Research 19(1): 38-43, https://doi.org/10.2478/v10012-012-0005-7.

30. Zakaria, K. A.; Abdullah, S.; Ghazali, M. J. 2013. Elevated temperature fatigue life investigation of Aluminium Alloy based on the predicted S-N curve, Jurnal Teknologi 63(1): 75-79. https://doi.org/10.11113/jt.v63.1345.

31. ASTM: B557M 2002. Standard Test Methods of Tension Testing Wrought and Cast Aluminum and Magnesium Alloy Products. ASTM International. West Conshohocken.

32. ASTM: E468-90 2004. Standard Practice for Presentation of Constant Amplitude Fatigue Test Results for Metallic Materials. ASTM International. West Conshohocken.
33. ASTM: E606-92 1998. Standard Practice for StrainControlled Fatigue Testing. ASTM International. West Conshohocken.

34. Kuwazuru, O.; Murata, Y.; Hangai, Y.; Utsunomiya, T.; Kitahara, S.; Yoshikawa, N. 2008. X-ray CT inspection for porosities and its effect on fatigue of die cast aluminium alloy, Journal of Solid Mechanics and Materials Engineering 2(9): 1 220-1231. https://doi.org/10.1299/jmmp.2.1220.

35. Skallerud, B.; Iveland, T.; Harkegard, G. 1993. Fatigue life assessment of aliminum alloys with casting defects, Engineering Fracture Mechanics 44(6): 857874. https://doi.org/10.1016/0013-7944(93)90108-5.

36. Wang, Q. G.; Apelian, D.; Lados, D. A. 2001. Fatigue behavior of A356-T6 aluminum cast alloys. Part I. Effect of casting defects, Journal of Light Metals 1(1): 73-84. https://doi.org/10.1016/S1471-5317(00)00008-0.

37. Couper, M. J.; Nesson, A. E.; Griffiths, J. R. 1990. Casting defects and the fatigue behavior of an aluminium casting alloy, Fatigue and Fracture of Engineering Materials and Structures 13(3): 213-227. https://doi.org/10.1111/j.1460-2695.1990.tb00594.x.

38. Rašuo, B. 2011. Experimental techniques for evaluation of fatigue characteristics of laminated constructions from composite materials: full-scale testing of the helicopter rotor blades, Journal of Testing and Evaluation 39(2): 237-242. https://doi.org/10.1520/JTE102768.

39. Linder, J.; Axelsson, M.; Nilsson, H. 2006. The influence of porosity on the fatigue life for sand and permanent mould cast aluminium, International Journal of Fatigue. 28(12): 1752-1758. https://doi.org/10.1016/j.ijfatigue.2006.01.001.

40. Lados, D. A.; Apelian, D. 2004. Fatigue crack growth characteristics in cast Al-Si-Mg alloys. Part I. Effects of processing conditions and microstructure, Materials Science and Engineering: A385(1-2): 200-211. https://doi.org/10.1016/j.msea.2004.06.073.

N. Vučetić, G. Jovičić, B. Krstić, M. Živković, V. Milovanović, J. Kačmarčik, R. Antunović

\section{FURTHER INVESTIGATION OF THE REPETITIVE FAILURE IN AN AIRCRAFT ENGINE CYLINDER HEAD - MECHANICAL PROPERTIES OF ALUMINUM ALLOY 242.0}

S u m m a r y

Aluminum alloys are widely used in military and aviation industry due to their properties such as low density and high strength. During the aircraft operation there are mechanical failures of various structural components caused by numerous mechanisms such as corrosion, material defects, high cycle fatigue and the like. One of the frequent mechanical failures on air-cooled piston engines is the cylinder head cracking. This paper is the continuation a comprehensive research of the Lycoming IO-360-B1F aircraft cylinder head failure. The failure of this type has already occurred during flight and about 50 failures like this have been registered from around the world, some of them with a fatal outcome and therefore require detailed research. 
The paper consists of machining of the tested specimens and their testing at many different locations and in many different laboratories throughout Bosnia and Herzegovina, Serbia and Slovenia. This paper is based on a research that includes the experimental analysis of mechanical properties of Aluminum alloy 242.0 which is a constituent material of the cylinder head of the Lycoming IO-360-B1F aircraft engine on which a crack appeared. Based on chemical, metallographic, static and dynamic experimental tests of the material properties, Aluminum alloy 242.0 static and fatigue properties were obtained, S-N curve was formed and endurance limit was determined. Results of numerical simulations of experiments, confirmed by experimental results, were performed to make numerical procedures reliable due to further research. The results of the research are planned to be implemented in numerical modeling of the cylinder assembly stress-strain state under workload and in further numerical research of Lycoming IO-360-B1F cylinder assembly integrity assessment.

Key words: Aluminum alloy 242.0, aircraft cylinder head, failure analysis, experimental tests, S-N curve, Finite element analysis.

Received October 31, 2019

Accepted August 24, 2020

This article is an Open Access article distributed under the terms and conditions of the Creative Commons Attribution 4.0 (CC BY 4.0) License (http://creativecommons.org/licenses/by/4.0/). 